\title{
Removal Characteristics of Organic Pollutants in Sewage Treatment by a Pre-Coagulation, Ozonation and Ozone/Hydrogen Peroxide Process
}

\section{$\operatorname{AUTHOR}(\mathrm{S})$ :}

Mizuno, Tadao; Tsuno, Hiroshi; Yamada, Harumi; Takeshima, Daisuke

\section{CITATION:}

Mizuno, Tadao ... [et al]. Removal Characteristics of Organic Pollutants in Sewage Treatment by a Pre-Coagulation, Ozonation and Ozone/Hydrogen Peroxide Process. Ozone: Science \& Engineering 2008, 30(4): 263-274

\section{ISSUE DATE:}

2008-07

URL:

http://hdl.handle.net/2433/95083

\section{RIGHT:}

This is an electronic version of an article published in [Tadao Mizuno; Hiroshi Tsuno; Harumi Yamada; Daisuke Takeshima. Removal Characteristics of Organic Pollutants in Sewage Treatment by a Pre-Coagulation, Ozonation and Ozone/Hydrogen Peroxide Process. Ozone: Science \& Engineering, 30(4), 2008, 263-274.]. [Ozone: Science \& Engineering] is available online at:

http://www.informaworld.com/smpp/content db=all?content=10.1080/01919510802097341.; この論文は出版社版であ りません。引用の際には出版社版をご確認ざ利用ください。; This is not the published version. Please cite only the published version. 


\title{
Removal characteristics of organic pollutants in sewage treatment by a pre-coagulation, ozonation and ozone/hydrogen peroxide process
}

\author{
Tadao Mizuno***, Hiroshi Tsuno***, Harumi Yamada*** \\ and Daisuke Takeshima**** \\ *Cooperative Research and Education Centre for Environmental Technology \\ (Kyoto University and Tsinghua University), \\ Tsinghua Campus, The University Town, Shenzhen, 518055, China \\ ***Department of Urban and Environmental Engineering, Kyoto University, \\ Katsura, Nishikyou-ku, Kyoto 615-8540, Japan \\ ***Japan Ozone Association, 1-3-9 Akasaka, Minato-ku, Tokyo 107-0052, Japan \\ ****Alumnus, Department of Urban and Environmental Engineering, Kyoto University \\ (E-mail: turbo-mzn@sz.tsinghua.edu.cn)
}

Received for review:

Accepted for publication:

\begin{abstract}
The applicability of a sequential process of ozonation and ozone/hydrogen peroxide process for the removal of soluble organic compounds from a pre-coagulated municipal sewage was examined. $6-25 \%$ of initial $\mathrm{T}-\mathrm{COD}_{\mathrm{Cr}}$ was removed at the early stage of ozonation before the ratio of consumed ozone to removed $\mathrm{T}-\mathrm{COD}_{\mathrm{Cr}}$ dramatically increased. Until dissolved ozone was detected, $0.3 \mathrm{mgO}_{3} / \mathrm{mgTOC}_{0}$ (Initial TOC) of ozone was consumed. When ozone/hydrogen peroxide process was applied, the more $\mathrm{COD}_{\mathrm{Cr}}$ was removed. And we elucidated that two following findings are important for the better performance of ozone/hydrogen peroxide process; those are to remove readily reactive organic compounds with ozone before the application of ozone/hydrogen peroxide process and to avoid the excess addition of hydrogen peroxide. Based on these two findings, we proposed a sequential process of ozonation and multi-stage ozone/hydrogen peroxide process and the appropriate addition of hydrogen peroxide. T-COD $\mathrm{Cr}$, TOC and ATU-BOD 5 were reduced to less than $7 \mathrm{mg} / \mathrm{L}, 6 \mathrm{mgC} / \mathrm{L}$ and $5 \mathrm{mg} / \mathrm{L}$, respectively after total treatment time of $79 \mathrm{~min}$. Furthermore, we discussed the transformation of organic compounds property and the removal of organic compounds. The removal amount of $\mathrm{COD}_{\mathrm{Cr}}$ and $\mathrm{UV}_{254}$ had good linear relationship until the removal amounts of $\mathrm{COD}_{\mathrm{Cr}}$ and $\mathrm{UV}_{254}$ were $30 \mathrm{mg} / \mathrm{L}$ and $0.11(1 / \mathrm{cm})$, respectively. Therefore $\mathrm{UV}_{254}$ would be useful for an indicator for $\mathrm{COD}_{\mathrm{Cr}}$ removal at the beginning of the treatment. The accumulation of carboxylic acids (formic acid, acetic acid and oxalic acid) was observed. The ratio of carbon concentration of carboxylic acids to TOC remaining was getting higher and reached around 0.5 finally. Removal of TOC was observed with the accumulation of carboxylic acids. When unknown organic
\end{abstract}


compounds (organic compounds except for carboxylic acids) was oxidized, its $70 \%$ was removed as carbon dioxide and its $30 \%$ was accumulated as carboxylic acids apparently. A portion of biodegradable organic compounds to whole organic compounds was enhanced as shown by the increase ratio of $\mathrm{BOD} / \mathrm{COD} \mathrm{Cr}$.

\section{Keywords}

Organic compounds, Sewage treatment, Ozonation, Ozone/hydrogen peroxide process, Pre-coagulation

\section{INTRODUCTION}

Ozonation is one of the promising technologies to remove organic pollutants, to oxidize organic and inorganic compounds, and to disinfect pathogenic micro-organisms in water and wastewater treatment. Ozonation of secondary effluent was examined with aim at removing $\mathrm{COD}_{\mathrm{Cr}}$. In the researches, about 20 to $30 \%$ of initial $\mathrm{COD}_{\mathrm{Cr}}$ was removed rapidly at the beginning of ozonation and then the efficiency was remarkably decreased (Goda et al., 1974; Somiya and Tsuno, 1975a; Somiya and Tsuno, 1975b; Paraskeva et al., 1998). Removal rate of $\mathrm{COD}_{\mathrm{Cr}}$ at the latter stage of ozonation was slowed down to the range from $1 / 30$ to $1 / 10$ of that at the beginning of ozonation (Goda et al., 1974; Somiya and Tsuno, 1975a). The amount of ozone required to remove $\mathrm{COD}_{\mathrm{Cr}}$ was in the range from 1 to $3 \mathrm{mgO}_{3} / \mathrm{mgCOD}_{\mathrm{Cr}}$ (Goda et al., 1974; Somiya and Tsuno, 1975a; Somiya and Tsuno, 1975b; Paraskeva et al., 1998). Different from $\mathrm{COD}_{\mathrm{Cr}}$, TOC was not reduced, namely mineralization was not appeared (Paraskeva et al., 1998). Shishida et al. (1999) examined the applicability of ozone/hydrogen peroxide process $\left(\mathrm{O}_{3} / \mathrm{H}_{2} \mathrm{O}_{2}\right)$ to remove TOC in secondary effluent after sand filtration. They showed that TOC was removed from $5 \mathrm{mgC} / \mathrm{L}$ to less than $2 \mathrm{mgC} / \mathrm{L}$. Yamada and Somiya (1980), and Kosaka et al. (2001) reported that acetic acid was formed during ozonation as well as $\mathrm{O}_{3} / \mathrm{H}_{2} \mathrm{O}_{2}$ of secondary effluent, respectively.

Beltrãn et al., (1997) studied ozonation and $\mathrm{O}_{3} / \mathrm{H}_{2} \mathrm{O}_{2}$ of primary effluent of sewage. In the case of ozonation, about $20 \%$ of initial $\mathrm{COD}_{\mathrm{Cr}}$ was removed rapidly at the beginning of ozonation and then the efficiency was remarkably decreased. The amount of ozone required for the removal of $\mathrm{COD}_{\mathrm{Cr}}$ was in the range from 1 to 2 $\mathrm{mgO}_{3} / \mathrm{mgCOD}_{\mathrm{Cr}}$. And it was reported that $\mathrm{O}_{3} / \mathrm{H}_{2} \mathrm{O}_{2}$ did not improve the removal efficiency of COD compared to ozonation. Up to now, appropriate processes and/or operational parameters of ozonation and $/$ or $\mathrm{O}_{3} / \mathrm{H}_{2} \mathrm{O}_{2}$ for the effective removal of organic pollutants from primary effluent, and the transformation property of organic pollutants have not been discussed. They may have come from lacks of attraction of ozonation due to the following reasons; biological treatment processes such as the activated sludge process have been widely accepted and they have been operated well to a certain extent, ozonation itself was an expensive treatment process from the aspects of initial cost as well as operational cost, namely the price of ozone generators was high and ozone generators consumed much electricity, ozone generators were not able to produce enough amount and concentration of ozone applicable to highly organic-polluted water, 
and proper ozone dissolution systems were not available. However they are not the case now. Because of the improvements of ozone generators, the price of ozone generators is getting lower and lower, they can produce larger amount and higher concentration of ozone gas and they are not energy-consumed equipments at present. And the activated sludge process has a problem of the production of excess sludge. With the advance of ozone generators and dissolution systems, the applicability of ozonation and/or $\mathrm{O}_{3} / \mathrm{H}_{2} \mathrm{O}_{2}$ for the removal of highly organic-polluted water must be studied.

The purpose of this study is to examine the applicability of ozonation and/or $\mathrm{O}_{3} / \mathrm{H}_{2} \mathrm{O}_{2}$ for the removal of organic compounds from a pre-coagulated municipal sewage. This study shows how extent organic compounds are removed by ozonation and/or $\mathrm{O}_{3} / \mathrm{H}_{2} \mathrm{O}_{2}$ and whether it is practically accepted. By the research, the applicability of ozonation and/or $\mathrm{O}_{3} / \mathrm{H}_{2} \mathrm{O}_{2}$ not only as an alternative process of activated sludge process but also for the removal of highly organic-polluted water without the production of excess sludge will be discussed. Finally, we propose a sequential ozonation and multi-stage $\mathrm{O}_{3} / \mathrm{H}_{2} \mathrm{O}_{2}$ as an appropriate process with appropriate operational parameters. The transformation property and the removal characteristics of organic compounds during ozonation and $\mathrm{O}_{3} / \mathrm{H}_{2} \mathrm{O}_{2}$ are evaluated as well.

\section{MATERIALS AND METHODS}

\section{Experimental set-up}

Schematic diagram of experimental set-up is shown in Figure 1. All components of experimental apparatus that contacts with ozone gas or ozonated water were composed of glass or Teflon ${ }^{\circledR}$. All ozonation experiments were conducted with a semi-batch type reactor. The inner diameter and the effective height of the reactor were $5 \mathrm{~cm}$ and $15 \mathrm{~cm}$, respectively, and hence the effective volume was $300 \mathrm{~mL}$. The reactor was filled with water sample first and then ozone gas was continuously fed to the reactor through a diffuser, which was set at the bottom of the reactor, during a given treatment time. Ozone which was produced by a PSA ozone generator (SGA-01A-PSA4, Sumitomo Precision Product Co., Ltd.) was passed through a phosphorus buffer solution to remove NOx before introduced into the reactor. Gas flow rate was adjusted through a flow meter (KOFLOC). Feed gas concentration was monitored continuously by an ozone monitor (EG-600, EBARA JITUGYO CO., LTD.) and exhaust gas from the reactor was absorbed by KI solution which was subsequently titrated by thiosulfate to evaluate the mass of exhaust ozone gas every experiment. Dissolved ozone in the reactor was determined by indigo method. Ozone consumption was evaluated based on the mass of input ozone gas, exhaust ozone gas and dissolved ozone concentration. All experiments were carried out under the constant temperature of $20^{\circ} \mathrm{C}$.

\section{Water sample}

Water sample tested was collected from a municipal wastewater treatment plant in Japan. Raw sewage collected was coagulated and settled to remove SS before ozonation and 
$\mathrm{O}_{3} / \mathrm{H}_{2} \mathrm{O}_{2}$. Every time raw sewage was collected, jar test was conducted to determine the optimum condition to remove SS as much as possible. And then the raw sewage was pre-treated by pre-coagulation and sedimentation under the optimum condition. Water quality of the raw sewage and that after coagulation and sedimentation, as well as the condition of pre-treament, coagulation and sedimentation, are shown in Table1. The concentrations of SS, T-COD $\mathrm{Cr}$, ATU-BOD $5, \mathrm{UV}_{254}$ and TOC in the raw sewage were in the range of $103-230 \mathrm{mg} / \mathrm{L}, 240-560 \mathrm{mg} / \mathrm{L}, 81-203 \mathrm{mg} / \mathrm{L}, 0.286-0.677(1 / \mathrm{cm})$ and 86-168 $\mathrm{mgC} / \mathrm{L}$, respectively. $\mathrm{NOx}$ was seldom detected. After coagulation and sedimentation, the concentrations of SS, T-COD $\mathrm{Cr}_{\mathrm{r}}, \mathrm{ATU}-\mathrm{BOD}_{5}, \mathrm{UV}_{254}$ and TOC were in the range of $1-9 \mathrm{mg} / \mathrm{L}, 58-103 \mathrm{mg} / \mathrm{L}, 22-32 \mathrm{mg} / \mathrm{L}, 0.138-0.257(1 / \mathrm{cm})$ and $21-29$ $\mathrm{mgC} / \mathrm{L}$, respectively. Because SS concentrations were decreased to less than $10 \mathrm{mg} / \mathrm{L}$ after coagulation and sedimentation, ozonation and $\mathrm{O}_{3} / \mathrm{H}_{2} \mathrm{O}_{2}$ were considered to be carried out to remove soluble organic compounds.

\section{Ozonation condition}

In ozonation experiments, the range of the concentration and the flow rate of supplied ozone gas were in the range of $25-100 \mathrm{mg} / \mathrm{L}$ and $50-200 \mathrm{~mL} / \mathrm{min}$., respectively. When $\mathrm{O}_{3} / \mathrm{H}_{2} \mathrm{O}_{2}$ was applied, the concentration of hydrogen peroxide was set at up to $50 \mathrm{mg} / \mathrm{L}$. Detail ozonation condition is shown in Table2. As for Run6, a sequential process of ozonantion and multi-stage $\mathrm{O}_{3} / \mathrm{H}_{2} \mathrm{O}_{2}$ was examined. Detail information will be shown later.

In order to obtain the treated water sample after a given treatment time in each series of experimental condition, a semi-batch experiment was repeated for each sample for a given treatment time independently. This is for the proper collection of exhaust ozone gas including the gas in head space of the reactor and for avoiding the mis-estimation of ozone mass balance due to the lag time of exhaust ozone gas. Special attention was paid to keep the water sample uniform before experiment.

\section{Analytical method}

Analytical method and instrument for the measurement of water quality items, ozone and hydrogen peroxide are summarized in Table3. Standard Methods (1998) was mainly followed for the conventional analysis. The condition of ion chromatographic method is shown in Table4. The analysis of hydrogen peroxide with DMP method is available in Baga et al. (1988) and Kosaka et al. (1998).

\section{RESULTS AND DISCUSSION}

\section{Decrease profiles of organic compounds}

The decrease profiles of T-COD $\mathrm{Cr}$ and TOC as a function of experimental time during ozonation and/or $\mathrm{O}_{3} / \mathrm{H}_{2} \mathrm{O}_{2}$ in Run4 are shown in Figure 2 as an example. T-COD $\mathrm{Cr}$ was removed at the beginning of ozonation and then its removal rate was remarkably getting 
slower. This phenomenon is similar to that of secondary effluent (Goda et al., 1974; Somiya and Tsuno, 1975a; Somiya and Tsuno, 1975b). The removal ratio of T-COD $\mathrm{Cr}_{\mathrm{r}}$ at the early stage before the ratio of consumed ozone to removed T-COD $\mathrm{Cr}$ dramatically increased, was in the range of $6-25 \%$ in all of the ozonation. During this period, TOC was seldom removed. Until $120 \mathrm{~min}$. of ozonation was carried out in Run4-1, the concentrations of T-COD ${ }_{\mathrm{Cr}}$ and TOC were reduced from $71 \mathrm{mg} / \mathrm{L}$ to $37 \mathrm{mg} / \mathrm{L}$ and from $24 \mathrm{mgC} / \mathrm{L}$ to $19 \mathrm{mgC} / \mathrm{L}$, respectively, although the removal rate of $\mathrm{T}-\mathrm{COD}_{\mathrm{Cr}}$ and $\mathrm{TOC}$ were getting slower with experimental time.

When hydrogen peroxide was applied, namely $\mathrm{O}_{3} / \mathrm{H}_{2} \mathrm{O}_{2}$ was carried out, the removal efficiency of T-COD $\mathrm{Cr}_{\mathrm{r}}$ and TOC was enhanced due to the accelerated production of hydroxyl radical which has high potential to mineralize organic compounds. The concentrations of T-COD ${ }_{\mathrm{Cr}}$ were $28 \mathrm{mg} / \mathrm{L}$ after $120 \mathrm{~min}$. in Run4-2, and $26 \mathrm{mg} / \mathrm{L}$ and 18 $\mathrm{mg} / \mathrm{L}$ after $90 \mathrm{~min}$. in Run4-3 and Run4-4, respectively. As for TOC, the same trend was observed. Although good performance of $\mathrm{O}_{3} / \mathrm{H}_{2} \mathrm{O}_{2}$ was obtained after a certain treatment period, the effect of addition of hydrogen peroxide was not obvious at the beginning of treatment in Run4 as well as in all Runs. This is due to the competitive reaction between reactive organic compounds and hydrogen peroxide to ozone. Because of the high reactivity of some portion of organic compounds with ozone, hydrogen peroxide could not react with ozone to produce hydroxyl radical. Consequently the effect of addition of hydrogen peroxide was not observed at the beginning of ozonation. It should be noted that organic compounds which react with ozone quickly must be firstly removed to obtain good performance of $\mathrm{O}_{3} / \mathrm{H}_{2} \mathrm{O}_{2}$.

Furthermore, although the mass of $\mathrm{T}-\mathrm{COD}_{\mathrm{Cr}}$ removed was most in Run4-4, the equivalent efficiency to the addition of hydrogen peroxide $(50 \mathrm{mg} / \mathrm{L})$ did not seem to be attained. Radical chain reaction is actually accelerated by adding hydrogen peroxide, but hydrogen peroxide plays a role of a scavenger for hydroxyl radical as well. Consequently radical chain reaction is inhibited by hydrogen peroxide when its concentration is too high. This is the second note that the excess addition of hydrogen peroxide must be avoided for the good performance of $\mathrm{O}_{3} / \mathrm{H}_{2} \mathrm{O}_{2}$.

\section{Dissolved ozone concentration during ozonation}

Profile of dissolved ozone concentration during ozonation which is evaluated as a function of ozone consumption/ $\mathrm{TOC}_{0}$ (initial TOC) is shown in Figure 3. This figure shows that dissolved ozone was not detected before the ratio of ozone consumption/ $/ \mathrm{TOC}_{0}$ reached around $0.3 \mathrm{mgO} / \mathrm{mgC}$. This ozone consumption of 0.3 $\mathrm{mgO}_{3} / \mathrm{mgC}$ corresponds to that of the period when organic compounds and hydrogen peroxide are competitive to ozone. We expect that good performance of $\mathrm{O}_{3} / \mathrm{H}_{2} \mathrm{O}_{2}$ would be obtained after this amount of ozone is applied to sewage.

\section{Efficiency of ozone/hydrogen peroxide process}

The removal amounts of $\mathrm{COD}_{\mathrm{Cr}}$ and TOC as a function of the consumption of hydrogen 
peroxide were evaluated in Figure 4 to examine the efficiency of $\mathrm{O}_{3} / \mathrm{H}_{2} \mathrm{O}_{2}$. In the period when $\mathrm{O}_{3} / \mathrm{H}_{2} \mathrm{O}_{2}$ works fairly well except for Run4-3 and 4-4, the values of 3.8 $\mathrm{mgCOD} \mathrm{Cr}_{\mathrm{C}} / \mathrm{mgH}_{2} \mathrm{O}_{2}$ and $1.2 \mathrm{mgTOC} / \mathrm{mgH}_{2} \mathrm{O}_{2}$ were attained for the removal of $\mathrm{COD}_{\mathrm{Cr}}$ and TOC, respectively. But as mentioned above, the removal efficiency of organic compounds in Run4-3 (TOC) and 4-4 (COD $\mathrm{Cr}_{\text {and }}$ TOC) was not as good as others.

In order to evaluate the appropriate hydrogen peroxide concentration, we calculated it under the following assumptions; (1) hydrogen peroxide plays a good role when the concentration of hydrogen peroxide is lower than $\mathrm{M}_{\mathrm{app}} \mathrm{mg} / \mathrm{L}$, and (2) the efficiency of $\mathrm{O}_{3} / \mathrm{H}_{2} \mathrm{O}_{2}$ is reduced to $\alpha(\alpha<1)$ when the concentration of hydrogen peroxide is higher than $\mathrm{M}_{\text {app }} \mathrm{mg} / \mathrm{L}$. The evaluation concept of appropriate hydrogen peroxide concentration is illustrated in Figure 5. Namely $\mathrm{M}_{\text {app }}$ and $\alpha$ in Run4 were calculated by the following equation with the data of Run4-3 and 4-4.

Removal amount of TOC by the addition of hydrogen peroxide

$$
=\alpha \cdot \mathrm{X}_{\mathrm{TOC}} \cdot\left(\mathrm{M}-\mathrm{M}_{\mathrm{app}}\right)+\mathrm{X}_{\mathrm{TOC}} \cdot\left(\mathrm{M}_{\mathrm{app}}-\mathrm{M}_{\mathrm{rem}}\right) \quad(\text { Equation 1) }
$$

where;

$\mathrm{X}_{\text {TOC: }}$ : removal efficiency ratio of TOC to hydrogen peroxide $\left(\mathrm{mgC} / \mathrm{mgH}_{2} \mathrm{O}_{2}\right)$

$\mathrm{M}_{\mathrm{app}}$ : maximum concentration of hydrogen peroxide which is appropriate for the removal of organic compound $\left(\mathrm{mgH}_{2} \mathrm{O}_{2} / \mathrm{L}\right)$

$\mathrm{M}$ : concentration of hydrogen peroxide which is higher than $\mathrm{M}_{\text {app }}\left(\mathrm{mgH}_{2} \mathrm{O}_{2} / \mathrm{L}\right)$

$\mathrm{M}_{\mathrm{rem}}$ : concentration of hydrogen peroxide which is remaining in water $\left(\mathrm{mg} \mathrm{H}_{2} \mathrm{O}_{2} / \mathrm{L}\right)$

$\alpha$ : reduced factor $(-)$

Here, the value of $\mathrm{X}_{\mathrm{TOC}}$ was obtained as $1.2 \mathrm{mgTOC} / \mathrm{mgH}_{2} \mathrm{O}_{2}$ from Figure $4(\mathrm{~B})$ as mentioned above.

$5.3 \mathrm{mg} / \mathrm{L}$ of $\mathrm{M}_{\text {app }}$ and 0.12 of $\alpha$ were obtained. Figure 6 shows that the comparison between calculation and experimental results of TOC removal for the verification of the concept shown in Figure 5. Good agreement was obtained. $5.3 \mathrm{mg} / \mathrm{L}$ of $\mathrm{M}_{\text {app }}$ was obtained from the experimental result in Run3-3 as well. $5 \mathrm{mg} / \mathrm{L}$ of hydrogen peroxide under the ozone gas condition of $50 \mathrm{mg} / \mathrm{L}$ and $50 \mathrm{~mL} / \mathrm{min}\left(0.028 \mathrm{~m}^{3} /\left(\mathrm{m}^{2} \cdot \mathrm{min}\right.\right.$. $\left.)\right)$ is an optimum condition. From the experimental results in Run5, 6.7 to $8.1 \mathrm{mg} / \mathrm{L}$ of hydrogen peroxide is an optimum condition under the sets of ozone gas condition of $100 \mathrm{mg} / \mathrm{L}$ and $50 \mathrm{~mL} / \mathrm{min}$. $\left(0.028 \mathrm{~m}^{3} /\left(\mathrm{m}^{2} \cdot \mathrm{min}.\right)\right)$, and $50 \mathrm{mg} / \mathrm{L}$ and $100 \mathrm{~mL} / \mathrm{min} .\left(0.056 \mathrm{~m}^{3} /\left(\mathrm{m}^{2}\right.\right.$. min.)) in this study. The appropriate hydrogen peroxide concentration was evaluated against the apparent transferred rate of ozone in Figure 7. Mass transfer coefficients $\mathrm{K}_{\mathrm{L}} \mathrm{a}$ of 0.12 and $0.23(1 / \mathrm{min}$.) at gas flow rates of $50 \mathrm{~mL} / \mathrm{min}$. and $100 \mathrm{~mL} / \mathrm{min}$. were derived from Mizuno (2005). And Tsuno (1993) summarized and showed that there was a good relationship between $\mathrm{K}_{\mathrm{L}}$ a $(1 / \mathrm{min}$.) and the gas flow rate across the cross section area $\left(\mathrm{m}^{3} /\left(\mathrm{m}^{2} \cdot \min .\right)\right)$. We can conclude that when the concentration of supplied ozone gas, and $\mathrm{K}_{\mathrm{L}} \mathrm{a}$ or the gas flow rate across the cross section area of supplied ozone gas are higher and larger, the appropriate hydrogen concentration can be higher. 


\section{Applicability of a sequential ozonation and multi-stage ozone/hydrogen peroxide process for the removal of organic compounds from pre-coagulated sewage}

A sequential ozonation and multi-stage $\mathrm{O}_{3} / \mathrm{H}_{2} \mathrm{O}_{2}$ shown in Figure 8 is proposed to attain the good performance of organic removal based on two findings mentioned above; to remove the readily reactive organic compounds with ozone before the application of $\mathrm{O}_{3} / \mathrm{H}_{2} \mathrm{O}_{2}$ and to avoid the addition of excess hydrogen peroxide. Ozonation is firstly carried out to remove the readily reactive organic compounds with ozone and then multi-stage $\mathrm{O}_{3} / \mathrm{H}_{2} \mathrm{O}_{2}$ follows to remove the remaining soluble organic compounds effectively under the optimum condition of hydrogen peroxide concentration. Ozonation was conducted until dissolved ozone was detected, and multi-stage $\mathrm{O}_{3} / \mathrm{H}_{2} \mathrm{O}_{2}$ was subsequently carried out for $15 \mathrm{~min}$. per each stage. 5 stages of sequential $\mathrm{O}_{3} / \mathrm{H}_{2} \mathrm{O}_{2}$ were repeated at most under the semi-batch operation.

Profiles of T-COD ${ }_{\mathrm{Cr}}$, TOC, ATU-BOD $, \mathrm{NOx}, \mathrm{DO}_{3}$ and $\mathrm{H}_{2} \mathrm{O}_{2}$ during the treatment are shown in Figure 9. As for organic compounds, the concentrations of T-COD $\mathrm{Cr}_{\mathrm{Cr}}$, TOC and ATU-BOD 5 were dramatically decreased from $80 \mathrm{mg} / \mathrm{L}, 29 \mathrm{mgC} / \mathrm{L}$ and $31 \mathrm{mg} / \mathrm{L}$ to less than $7 \mathrm{mg} / \mathrm{L}, 6 \mathrm{mgC} / \mathrm{L}$ and $5 \mathrm{mg} / \mathrm{L}$, respectively, after total treatment time of $79 \mathrm{~min}$. The concentration of NOx was slightly increased from 0.3 to $3.5 \mathrm{mgN} / \mathrm{L}$ against the initial ammonium nitrogen concentration of $26 \mathrm{mgN} / \mathrm{L}$, as the reaction rate constants of $\mathrm{NH}_{4}{ }^{+}\left(\mathrm{p} K_{\mathrm{a}}=9.3\right)$ with ozone as well as hydroxyl radical are very low or almost zero (Hoingé and Bader, 1978). The amount of $\mathrm{H}_{2} \mathrm{O}_{2}$ consumed was gradually increased. This is because organic compounds which are competitors to $\mathrm{H}_{2} \mathrm{O}_{2}$ with ozone are decreased, hence the amount of ozone which reacts with $\mathrm{H}_{2} \mathrm{O}_{2}$ is gradually increased. And also radical chain reaction may be accelerated due to the depletion of organic compounds which inhibit radical chain reaction. Dissolved ozone concentration after 15 min. in each stage was in the range from 1 to $3 \mathrm{mg} / \mathrm{L}$ and was once increased and then decreased through the stage. In the former stage, although readily reactive organic compounds are removed, remaining organic compounds may react with ozone. In the latter stage, due to the promotion of radical chain reaction which involves the reaction of ozone, the concentration of dissolved ozone may be lower.

\section{Transformation of organic compounds properties}

Relationship between $\mathrm{COD}_{\mathrm{Cr}}$ and TOC is shown in Figure 10(A). The following relationship was obtained in the concentration range under $100 \mathrm{mg} / \mathrm{L}$ of $\mathrm{COD}_{\mathrm{Cr}}$ and 30 $\mathrm{mgC} / \mathrm{L}$ of TOC.

$\mathrm{TOC}=2.4 \mathrm{COD}_{\mathrm{Cr}}^{0.55}\left(\mathrm{R}^{2}=0.869\right)$

(Equation 2)

Based on the Equation 2, the ratio of TOC to $\mathrm{COD}_{\mathrm{Cr}}\left(\mathrm{TOC} / \mathrm{COD} \mathrm{D}_{\mathrm{Cr}}\right)$ was evaluated as a function of $\mathrm{COD}_{\mathrm{Cr}}$ concentration as illustrated in Figure 10(B). This figure shows that the ratio of $\mathrm{TOC} / \mathrm{COD}_{\mathrm{Cr}}$ increases with the decrease of organic compounds and the ratio is getting larger sharply at around $30 \mathrm{mg} / \mathrm{L}$ of $\mathrm{COD}_{\mathrm{Cr}}$. This is because $\mathrm{COD}_{\mathrm{Cr}}$ is removed rapidly and TOC is removed slightly at the beginning of ozonation, namely the 
oxidation of organic compounds occurs first and then mineralization of organic compounds appears.

Figure 11 shows the relationship between $\mathrm{COD}_{\mathrm{Cr}}$ concentration and $\mathrm{UV}_{254}$ value, and between the removal amount of $\mathrm{COD}_{\mathrm{Cr}}$ and that of $\mathrm{UV}_{254}$ during the treatment. When $\mathrm{COD}_{\mathrm{Cr}}$ concentration and $\mathrm{UV}_{254}$ value are higher, namely at the beginning of ozonation and $\mathrm{O}_{3} / \mathrm{H}_{2} \mathrm{O}_{2}, \mathrm{UV}_{254}$ seems to decrease with the decrease of $\mathrm{COD}_{\mathrm{Cr}}$. But the removal amount of $U_{254}$ was getting smaller during the treatment. The good linear relationship between the removal amount of $\mathrm{COD}_{\mathrm{Cr}}$ and that of $\mathrm{UV}_{254}\left(\Delta \mathrm{UV}_{254} / \Delta \mathrm{COD}_{\mathrm{Cr}}=0.0036\right.$, $\mathrm{R}^{2}=0.588, \mathrm{UV}_{254}<0.11 \mathrm{~cm}^{-1}$ ) was observed until the amount of $\mathrm{COD}_{\mathrm{Cr}}$ removed was 30 $\mathrm{mg} / \mathrm{L}$ and the amount of $\mathrm{UV}_{254}$ decreased was $0.11(1 / \mathrm{cm})$. This result shows that $\mathrm{UV}_{254}$ is likely to an alternative indicator of $\mathrm{COD}_{\mathrm{Cr}}$ while ozone is consumed by organic compounds rapidly at the beginning of ozonation and $\mathrm{O}_{3} / \mathrm{H}_{2} \mathrm{O}_{2}$.

Carboxylic acids such as formic acid, acetic acid and oxalic acid were determined as well as T-COD $\mathrm{Cr}$, TOC and ATU-BOD 5 . Figure 12 shows examples of profile of three carboxylic acids during the treatment in Run6-2 and 6-3. The concentration is expressed as carbon concentration and "unknown" represents organic compounds except for these three carboxylic acids. The accumulation of organic acids was observed and in particular formic acid and oxalic acid were formed during $\mathrm{O}_{3} / \mathrm{H}_{2} \mathrm{O}_{2}$. The removal of unknown compounds was observed as well. Consequently, the ratio of carboxylic acids to TOC was getting higher and reached around 0.5 .

All the results were analyzed for the evaluation of the ratio of carboxylic acids to TOC as a function of TOC and that of the removal amount of TOC as shown in Figure 13. The ratio of carboxylic acids to TOC of pre-coagulated samples was in the wide range from 0.07 to 0.27 under the concentration of TOC from 20.6 to $28.4 \mathrm{mgC} / \mathrm{L}$. As TOC was removed, the ratio was getting higher to be around 0.5 and reached plateau.

Relationships between the removal amount of unknown compounds and those of TOC and carboxylic acids were examined in Figure 14. TOC was removed as unknown organic compounds were disappeared and $70 \%$ of unknown organic compounds was removed as carbon dioxide with $30 \%$ of accumulation of carboxylic acids apparently.

When ozone is applied to remove organic compounds, the enhancement of biodegradability is one of the issues. Although $\mathrm{BOD}_{5}$ was slightly increased at a few minutes of treatment in some cases, it was normally decreased as a function of time or stage in many cases in this study. The relationship between the concentrations of $\mathrm{COD}_{\mathrm{Cr}}$ and $\mathrm{BOD}_{5}$ was summarized in Fig.15 (A). Totally we can conclude that the concentration of $\mathrm{BOD}_{5}$ was decreased with the removal of $\mathrm{COD}_{\mathrm{Cr}}$. Then the ratio of ATU-BOD 5 to $\mathrm{COD}_{\mathrm{Cr}}$ was evaluated in Fig15 (B). The ratio was getting higher to around $0.6 \sim 0.7$ with the decrease of $\mathrm{COD}_{\mathrm{Cr}}$ in ozonation and $\mathrm{O}_{3} / \mathrm{H}_{2} \mathrm{O}_{2}$. These results 
show that although the amount of biodegradable organic compounds is decreased, the portion of biodegradable organic compounds to total organic compounds is increased with the decrease of $\mathrm{COD}_{\mathrm{Cr}}$. Moreover the enhancement of the ratio is derived from the decrease of $\mathrm{COD}_{\mathrm{Cr}}$ rather than the production of $\mathrm{BOD}_{5}$ in ozonation and $\mathrm{O}_{3} / \mathrm{H}_{2} \mathrm{O}_{2}$ of pre-coagulated sewage in this study.

\section{CONCLUSION}

The applicability of a sequential process of ozonation and $\mathrm{O}_{3} / \mathrm{H}_{2} \mathrm{O}_{2}$ for removal of organic compounds from a pre-coagulated municipal sewage was examined. $6-25 \%$ of initial $\mathrm{T}-\mathrm{COD} \mathrm{Cr}_{\mathrm{r}}$ was removed at the early stage of ozonation before the ratio of consumed ozone to removed $\mathrm{T}-\mathrm{COD}_{\mathrm{Cr}}$ was dramatically increased. Until dissolved ozone was detected, $0.3 \mathrm{mgO}_{3} / \mathrm{mgTOC}_{0}$ (Initial TOC) of ozone was consumed. In the case of $\mathrm{O}_{3} / \mathrm{H}_{2} \mathrm{O}_{2}$, although the better removal of organic compounds than ozonation was attained in a certain reaction time, the effect of addition of hydrogen peroxide was not obvious at the beginning of treatment. This is due to the competitive reaction of highly reactive organic compounds and hydrogen peroxide to ozone. Furthermore, when the concentration of hydrogen peroxide was too high, the removal efficiency of organic compounds was depressed. $5 \mathrm{mg} / \mathrm{L}$ of hydrogen peroxide under the ozone gas condition of $50 \mathrm{mg} / \mathrm{L}$ and $50 \mathrm{~mL} / \mathrm{min}$. $\left(0.028 \mathrm{~m}^{3} /\left(\mathrm{m}^{2} \cdot \mathrm{min}\right.\right.$. $\left.)\right)$ is an optimum condition and 7 to 8 $\mathrm{mg} / \mathrm{L}$ of hydrogen peroxide is an optimum condition under the ozone gas condition of $100 \mathrm{mg} / \mathrm{L}$ and $50 \mathrm{~mL} / \mathrm{min}$. $\left(0.028 \mathrm{~m}^{3} /\left(\mathrm{m}^{2} \cdot \min .\right)\right)$, and $50 \mathrm{mg} / \mathrm{L}$ and $100 \mathrm{~mL} / \mathrm{min}$. $(0.056$ $\left.\mathrm{m}^{3} /\left(\mathrm{m}^{2} \cdot \min .\right)\right)$. We can elucidate that when the concentration of supplied ozone gas, and $\mathrm{K}_{\mathrm{L}} \mathrm{a}$ or gas flow rate across the cross section area of supplied ozone gas, hence the amount of supplied ozone are larger, the appropriate hydrogen concentration can be higher. Based on two findings, such as to remove readily reactive organic compounds with ozone before the application of $\mathrm{O}_{3} / \mathrm{H}_{2} \mathrm{O}_{2}$ and to avoid the addition of excess amount of hydrogen peroxide, a sequential process of ozonation and multi-stage ozone/hydrogen peroxide process was proposed and carried out. As a result, T-COD $\mathrm{Cr}$, TOC and ATU-BOD 5 were reduced to less than $7 \mathrm{mg} / \mathrm{L}, 6 \mathrm{mgC} / \mathrm{L}$, and $5 \mathrm{mg} / \mathrm{L}$, respectively after total treatment time of $79 \mathrm{~min}$. While $\mathrm{O}_{3} / \mathrm{H}_{2} \mathrm{O}_{2}$ worked well, the removal efficiency of $\mathrm{COD}_{\mathrm{Cr}}$ and $\mathrm{TOC}$ of $3.8 \quad \mathrm{mgCOD}_{\mathrm{Cr}} / \mathrm{mgH}_{2} \mathrm{O}_{2}$ and 1.2 $\mathrm{mgTOC} / \mathrm{mgH}_{2} \mathrm{O}_{2}$ was attained, respectively.

Transformation of organic compounds property and removal characteristics of organic compounds during the treatment were discussed as well. The removal amount of $\mathrm{COD}_{\mathrm{Cr}}$ and $\mathrm{UV}_{254}$ had good linear relationship until the decrease amount of $\mathrm{COD}_{\mathrm{Cr}}$ and $\mathrm{UV}_{254}$ was $30 \mathrm{mg} / \mathrm{L}$ and $0.11(1 / \mathrm{cm})$, respectively. Because this period almost corresponded to the period when ozone was consumed rapidly by organic compounds, $\mathrm{UV}_{254}$ would be useful for an indicator of $\mathrm{COD}_{\mathrm{Cr}}$ removal at the beginning of treatment. The accumulation of carboxylic acids such as formic acid, acetic acid and oxalic acid was observed. The ratio of carbon concentration of carboxylic acids to TOC was getting higher and reached around 0.5 finally. Removal of TOC was observed with the accumulation of carboxylic acids. When unknown organic compounds which are organic compounds except for three carboxylic acids, was removed, its $70 \%$ was removed as carbon dioxide and its $30 \%$ was accumulated as carboxylic acids apparently. 
The portion of biodegradable $\mathrm{COD}_{\mathrm{Cr}}$ was increased as shown by the increase of the ratio of $\mathrm{BOD} / \mathrm{COD} \mathrm{Cr}$.

Because a sequential ozonation and ozone/hydrogen peroxide process as well as coagulation is a physico-chemical treatment process, it is easy to operate and they don't require long time to get stability of treatment like the acclimation of micro-organisms. The sequential process of pre-coagulation, ozonation and $\mathrm{O}_{3} / \mathrm{H}_{2} \mathrm{O}_{2}$ is a promising technology to remove organic compounds in sewage as not only an alternative technology of existing activated sludge process but also decentralized system of sewage treatment and/or sewage treatment system dealing with small amount of water.

\section{REFERENCES}

1) APHA, AWWA, and WEF "Standard methods for the examination of water and wastewater $20^{\text {th }}$ edition", APHA, Washington, DC (1998)

2) Baga, A. N., Johnson, G. R. A., Nazhat, N. B., and Saadalla-Nazhat, R. A. "A simple spectrophotometric determination of hydrogen peroxide at low concentrations in aqueous solution", Anal. Chim, Acta., 204: 349-353 (1988)

3) Beltrãn, F. J., Garacía-Araya, J. F. and Álvarez, P. "Impact of chemical oxidation on biological treatment of a primary municipal wastewater. 1. Effects on COD and biodegradability”, Ozone Sci. \& Eng., 19: 495-512 (1997)

4) Goda, T., Kawara, O. and Eda, M. "Kinetics of ozonation -secondary effluent-“, Journal of Japan Sewage Works Association, 123: 41-49 (1974) (in Japanese)

5) Hoingé, J. and Bader, H. "Ozonation of water: Kinetics of oxidation of ammonia by ozone and hydroxyl radicals", Environ. Sci. \& Technol., 12: 79-84 (1978)

6) Kosaka, K., Yamada, H., Matsui, S., Echigo, S., and Shishida, K. "Comparison among the methods for hydrogen peroxide measurements to evaluate advanced oxidation processes: Application of a spectrophotometric method using copper (II) ion and 2,9-dimethyl-1,10-phenanthroline", Environ. Sci. Technol., 32: 3821-3824 (1998)

7) Kosaka, K., Yamada, H., Shishida, K., Echigo, S., Minear, R. A., Tsuno, H. and Matsui, S. "Evaluation of the treatment performance of a multistage ozone/hydrogen peroxide process by decomposition by-products", Water Res., 35: 3587-3594 (2001)

8) Mizuno, T. "Applicability and operational parameters of ozonation and ozone/hydrogen peroxide process for the removal of organic compound", Doctor Dissertation, Kyoto University (2005) (in Japanese)

9) Paraskeva, P., Lambert, S. D. and Graham, N. J. D. "Influence of ozoantion conditions on the treatability of secondary effluents", Ozone Sci. \& Eng., 20: 133-150 (1998).

10) Shishida, K., Tabasaki, M., Yamada, H. and Matsui, S. "Treatment applicability of ozone/hydrogen peroxide process of secondary effluent", Journal of Japan Sewage Works Association , 443: 123-133 (1999) (in Japanese)

11) Somiya, I., and Tsuno, H. "Ozonation of secondary effluent in a counter-current ozone reactor (I)", Water purification and liquid wastes treatment, 16: 647-658 (1975a) (in Japanese) 
12) Somiya, I., and Tsuno, H. "Ozonation of secondary effluent in a counter-current ozone reactor (II)", Water purification and liquid wastes treatment, 16: 725-737 (1975b) (in Japanese)

13) Tsuno, H. "Ozone reactor", Proceedings of $11^{\text {th }}$ lecture on ozone technology, Japan Ozone Association, 53-61 (1993) (in Japanese)

14) Yamada, H. and Somiya, I. "Identification of products resulting from ozonation of organic compounds in water", Ozone Sci. Eng., 2: 251-260 (1980) 


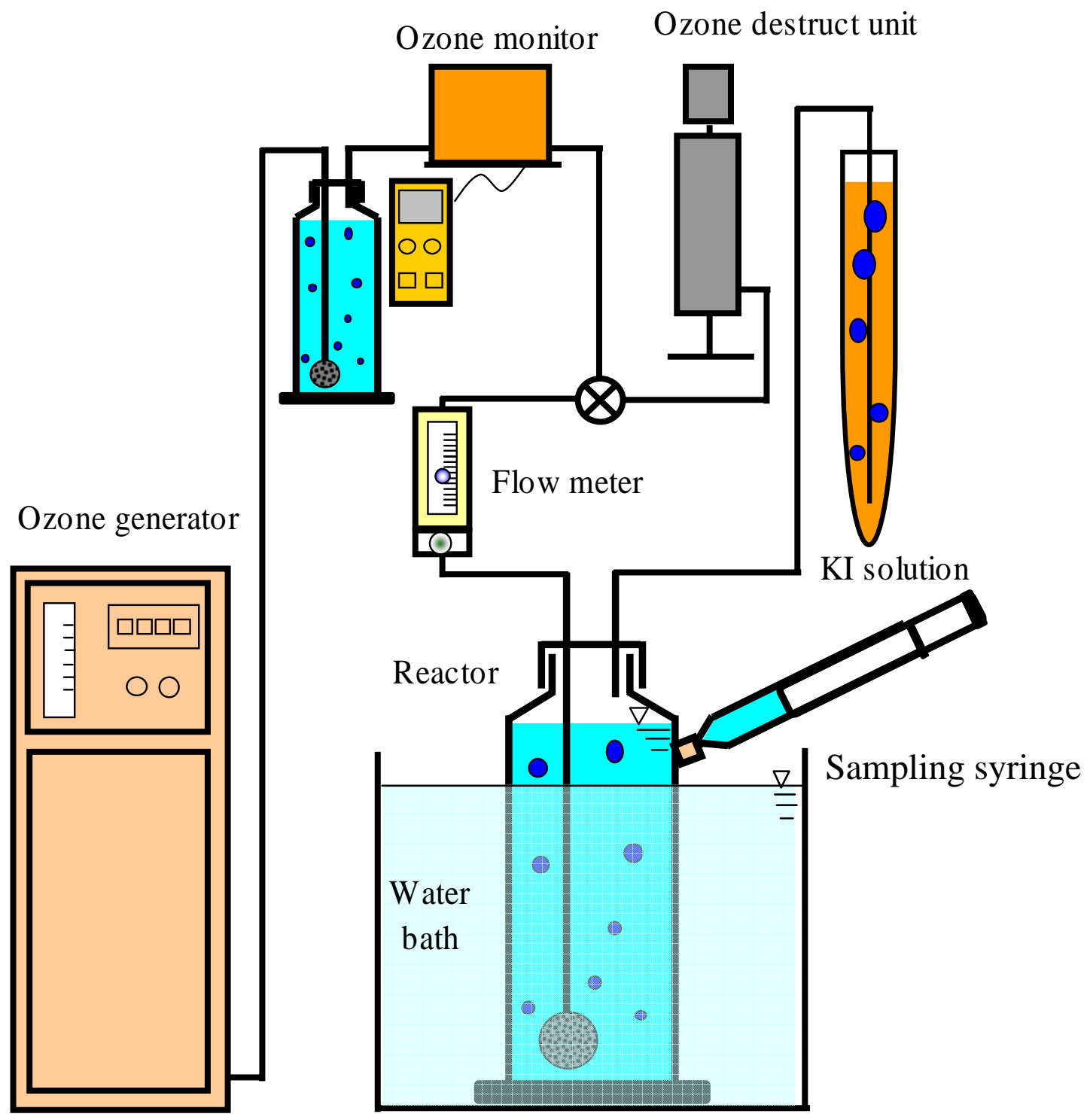

Fig. 1 Schematic diagram of experimetal set-up 


\begin{tabular}{|c||c|c|c|c|}
\hline & $4-1$ & $4-2$ & $4-3$ & $4-4$ \\
\hline Gas conc. $(\mathrm{mg} / \mathrm{L})$ & \multicolumn{4}{|c|}{50} \\
\hline Flow rate $(\mathrm{mL} / \mathrm{min})$. & \multicolumn{4}{|c|}{50} \\
\hline $\mathrm{H}_{2} \mathrm{O}_{2}$ conc. $(\mathrm{mg} / \mathrm{L})$ & 0 & 4 & 15 & 50 \\
\hline Legend & $\Delta \Delta$ & $\mathrm{O}$ & $\square$ & $\diamond$ \\
\hline
\end{tabular}

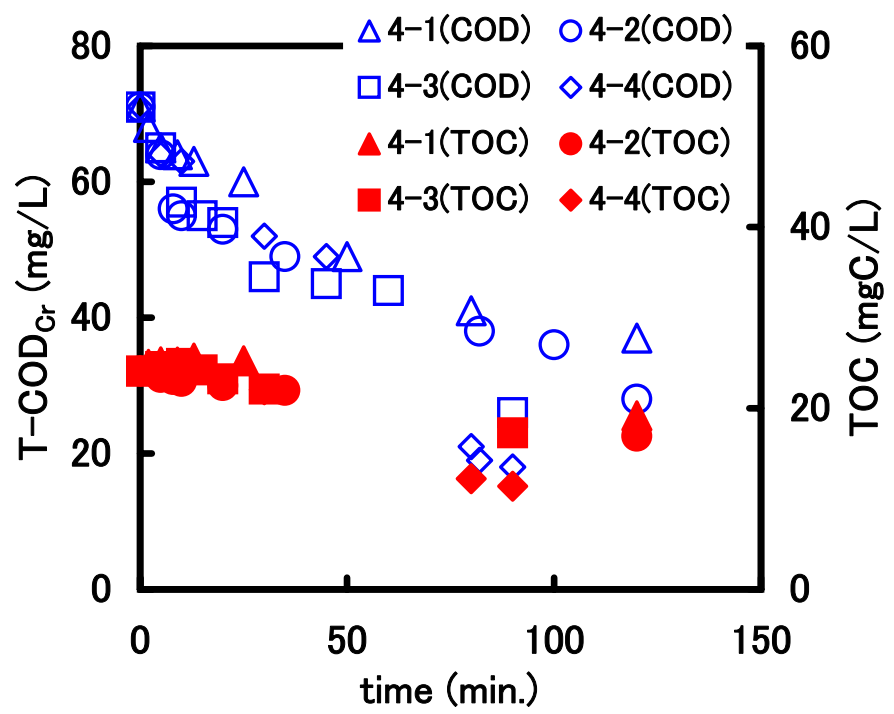

Fig. 2 Profiles of T-COD $\mathrm{Cr}$ (open) \& TOC (close) as a function of experimental time 


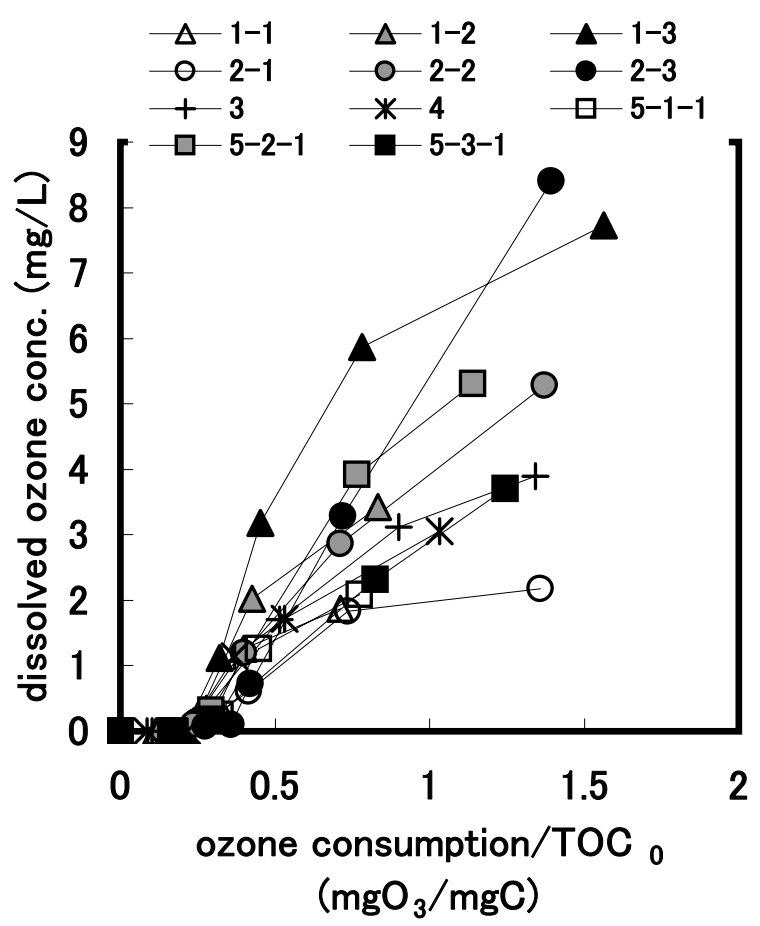

Fig. 3 Profiles of dissolved ozone concentration as a function of ozone consumption/initial TOC 
(A)

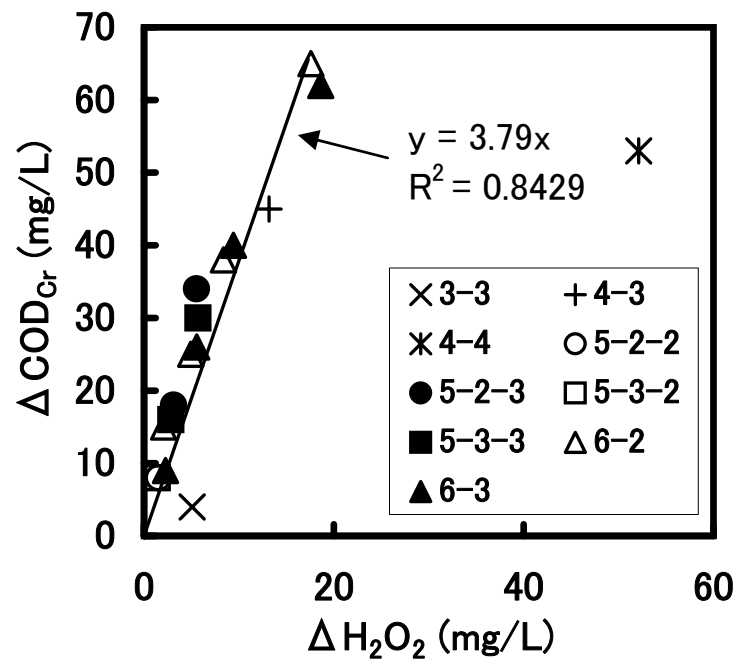

(B)

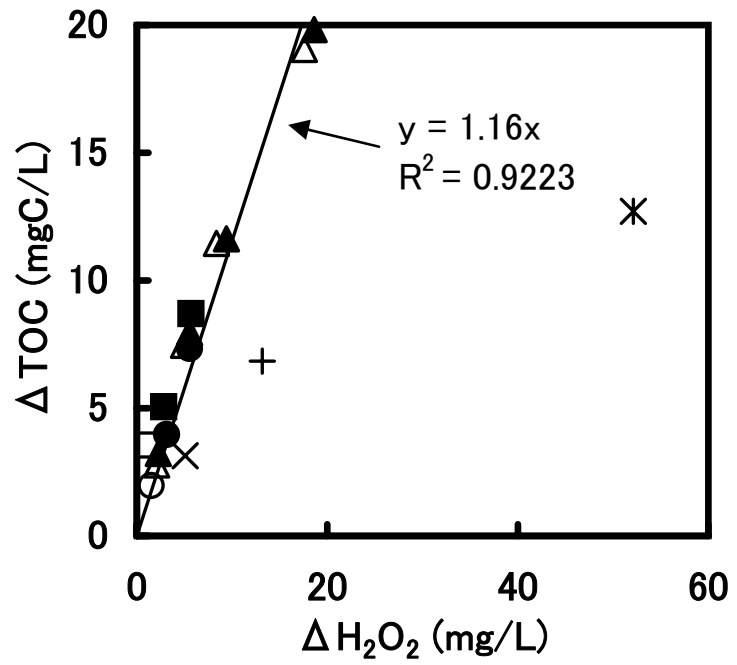

Fig. 4 Removal amount of $(A) C_{C O}$ and $(B) T O C$ as a function of hydrogen peroxide consumption

(Data of Run4-3(B) and 4-4(A,B) are excluded for the calculation of regression lines) 


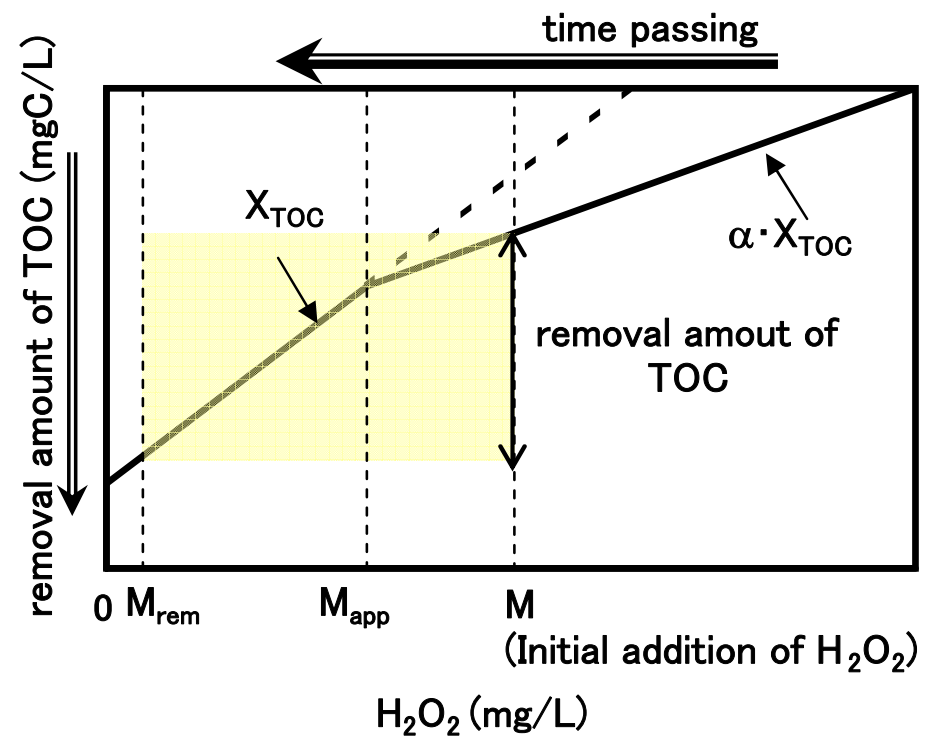

Fig. 5 Evaluation concept of appropriate hydrogen peroxide concentration for removal of organic compounds 


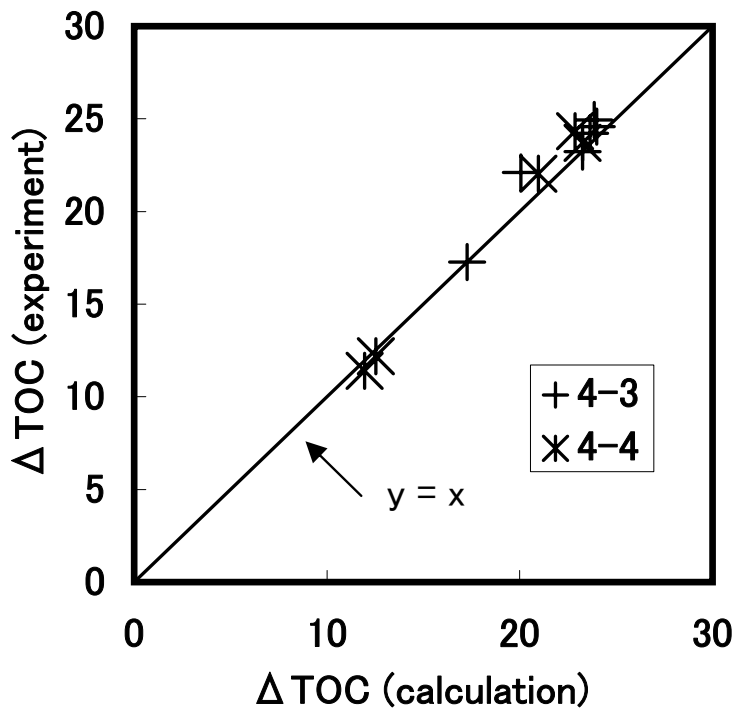

Fig. 6 Comparison between calculation and experimental results of TOC removal for the verification of concept shown in Figure 5 


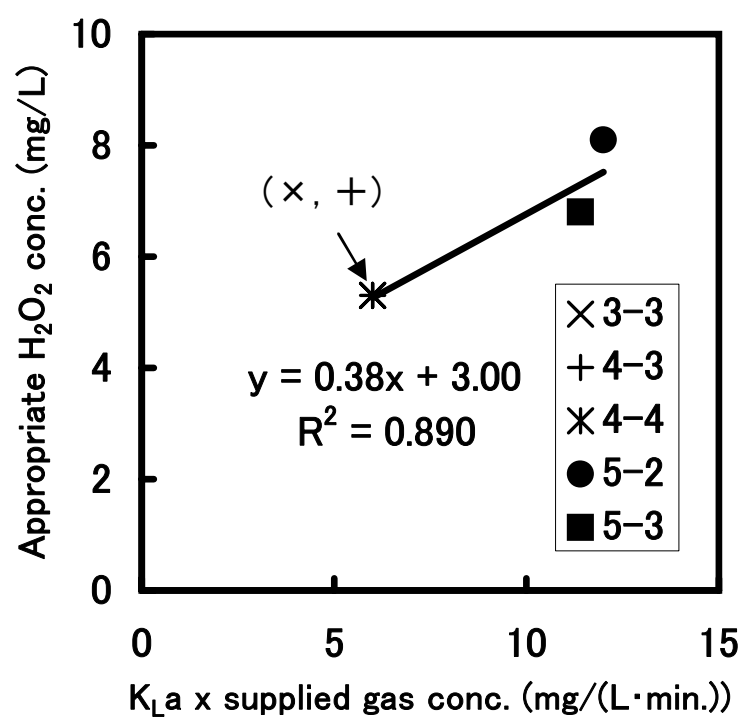

Fig. 7 Appropriate hydrogen peroxide concentration the against apparent transferred rate of ozone 


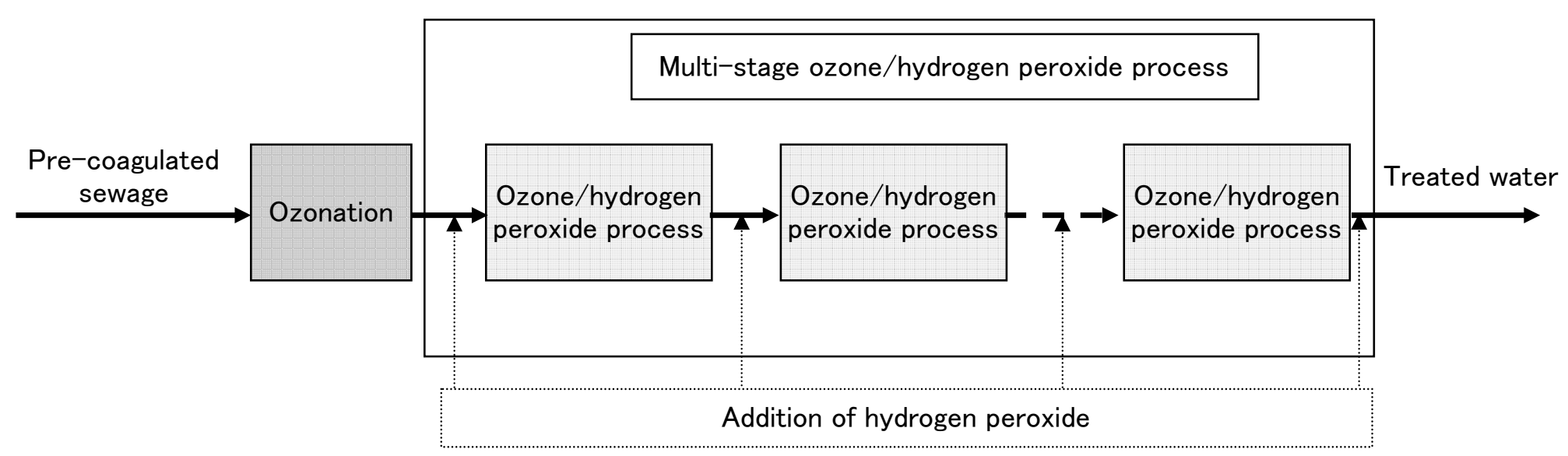

Fig. 8 Ozonation and multi-stage ozone/hydrogen peroxide process 


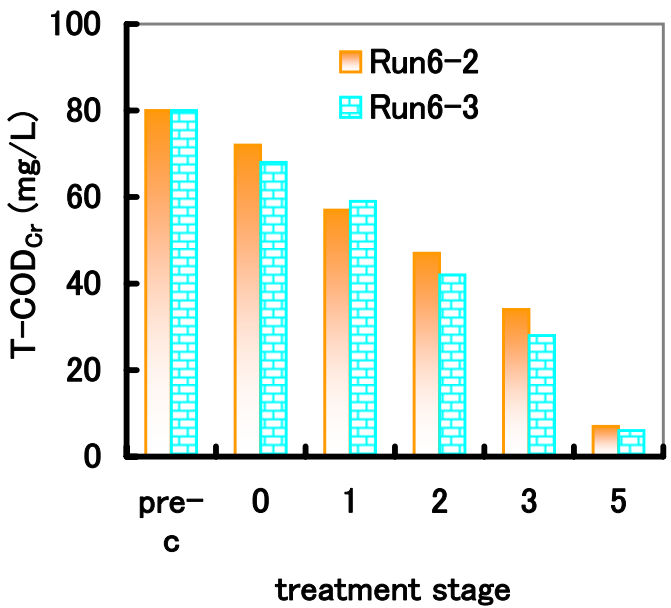

(A) $\mathrm{T}-\mathrm{COD}_{\mathrm{Cr}}$

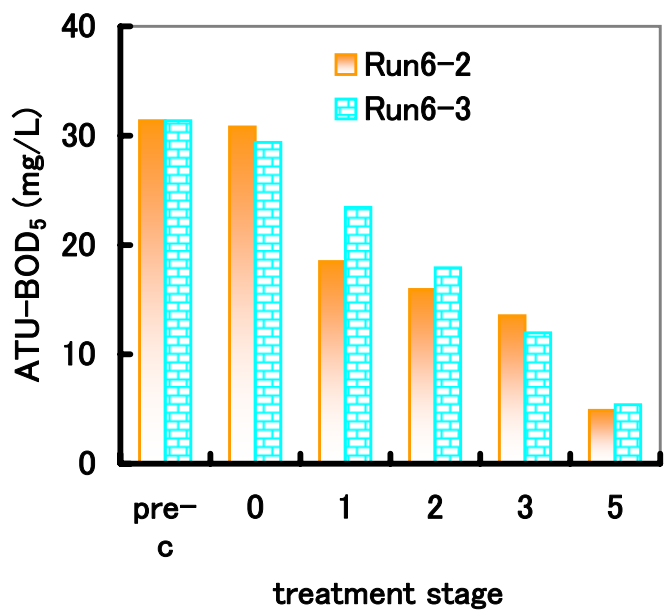

(C) ATU-BOD 5

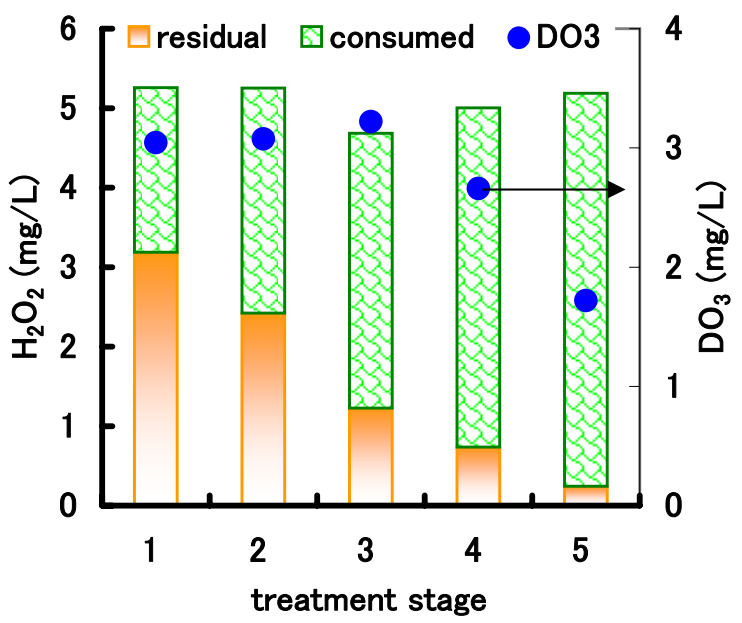

(E) $\mathrm{H}_{2} \mathrm{O}_{2}$ and $\mathrm{DO}_{3}$ (Run6-2)

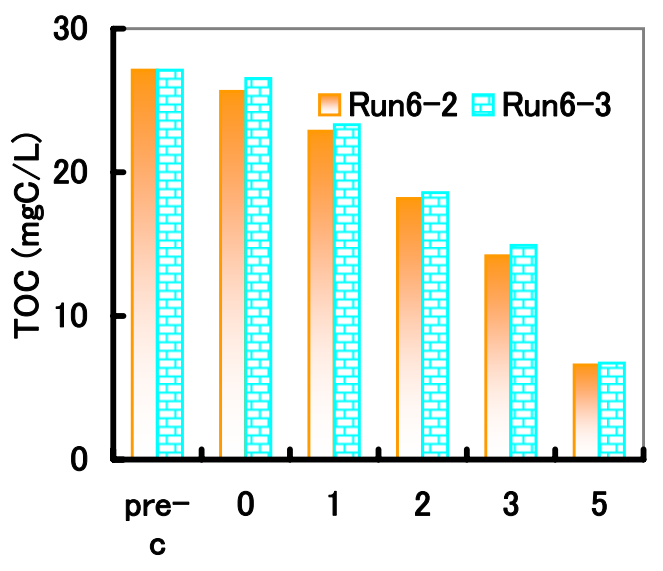

treatment stage

(B) TOC

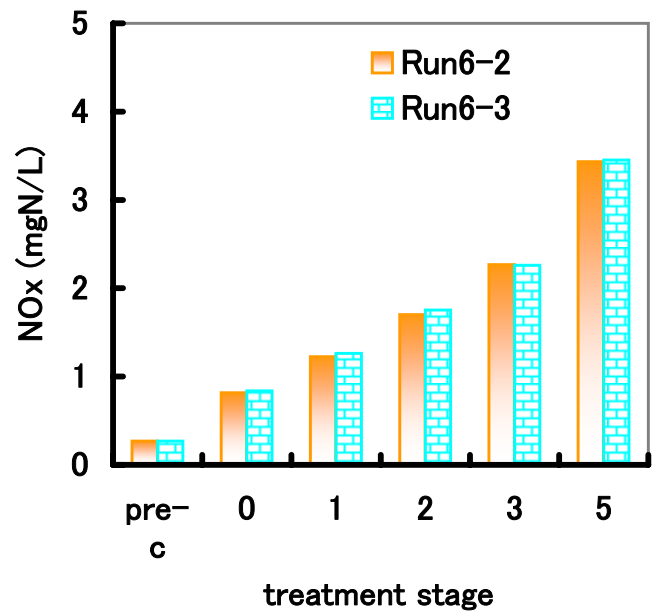

(D) NOx

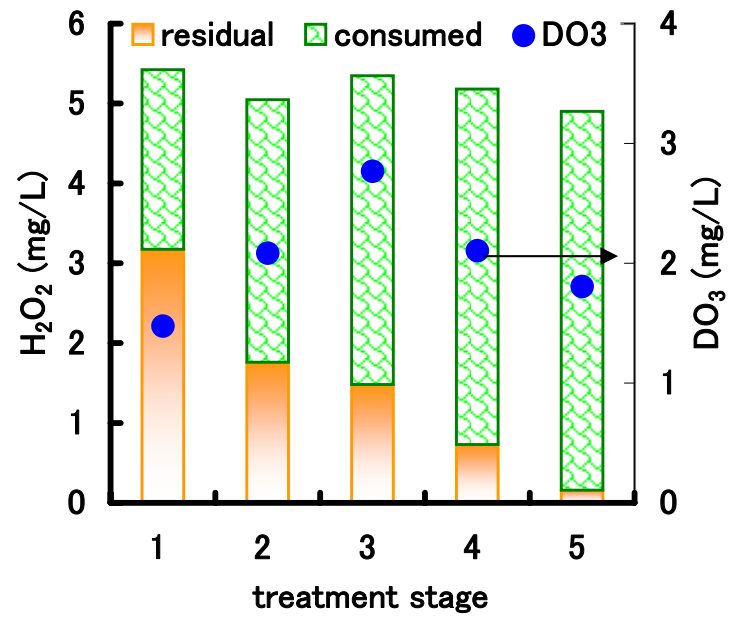

(F) $\mathrm{H}_{2} \mathrm{O}_{2}$ and $\mathrm{DO}_{3}$ (Run6-3)

Fig. 9 Profiles of $\mathrm{T}-\mathrm{COD}_{\mathrm{Cr}}$, TOC, ATU-BOD $, \mathrm{NOx}, \mathrm{DO}_{3}$ and $\mathrm{H}_{2} \mathrm{O}_{2}$ (Run6-2 \& Run6-3) in a sequential process of ozonation (stage 0 ) and multi-stage ozone/hydrogen peroxide process (stage1-5)

(pre-c: pre-coagulation, dissolved ozone concentration is represented by that after treatment of each stage) 
(A)

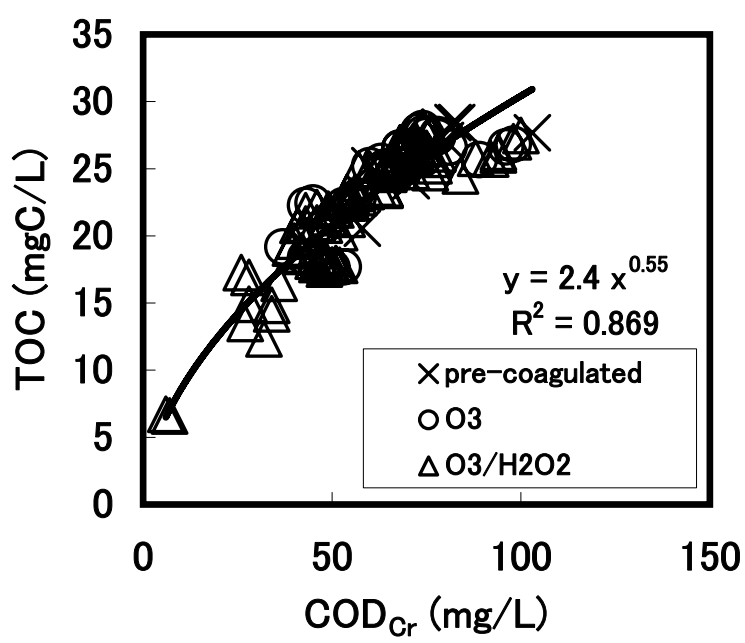

(B)

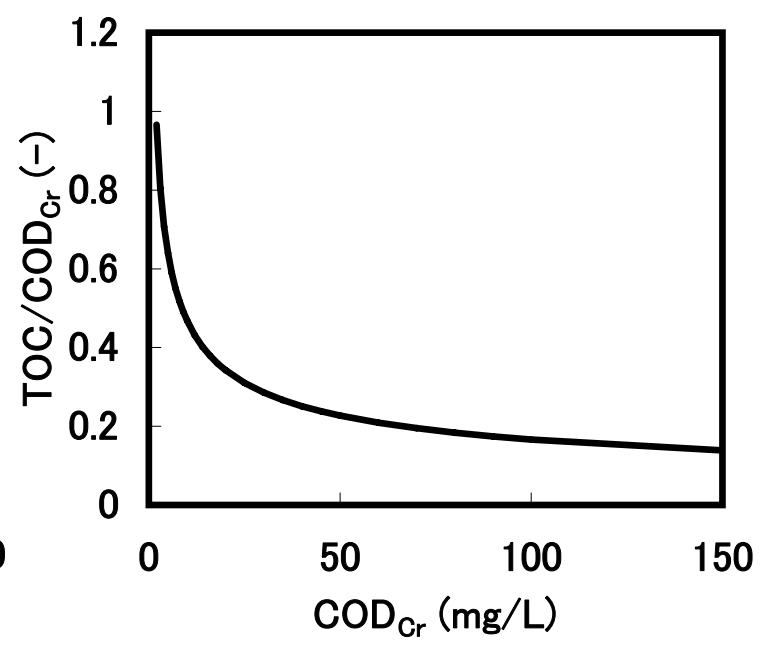

Fig. 10 (A) Relationship between $\mathrm{COD}_{\mathrm{Cr}}$ and $\mathrm{TOC}$ and (B) the ratio of $T O C / \mathrm{COD}_{\mathrm{Cr}}$ as a function of $\mathrm{COD}_{\mathrm{Cr}}$ during ozonation and $\mathrm{O}_{3} / \mathrm{H}_{2} \mathrm{O}_{2}$ 
(A)

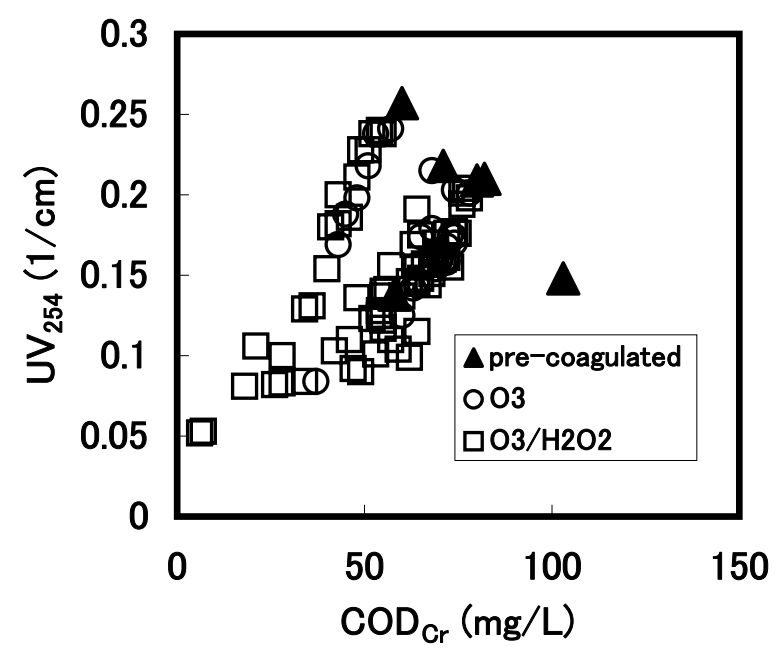

(B)

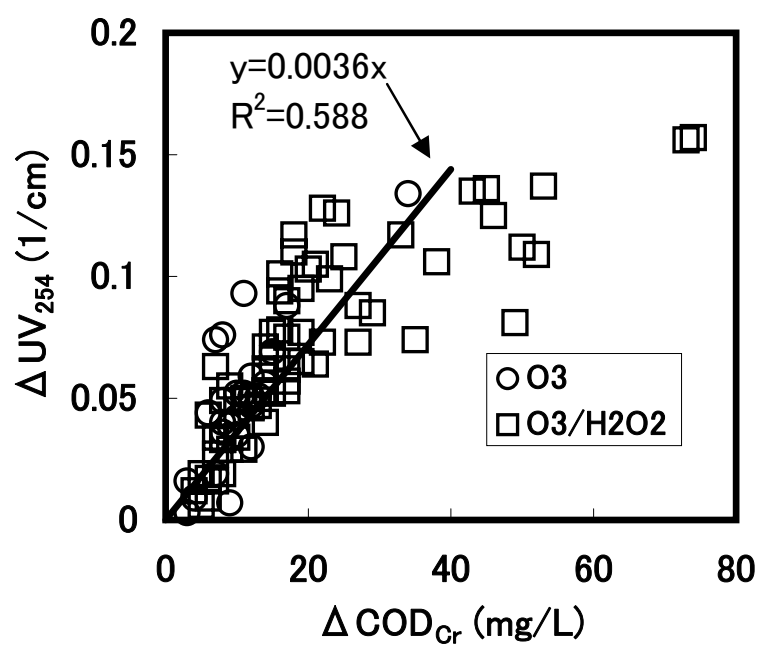

Fig. 11 (A) Relationship between the concentration of $\mathrm{COD}_{\mathrm{Cr}}$ and $\mathrm{UV}_{254}$ and (B) relationship between the removal amount of $\mathrm{COD}_{\mathrm{Cr}}$ and $\mathrm{UV}_{254}$ during ozonation and $\mathrm{O}_{3} / \mathrm{H}_{2} \mathrm{O}_{2}$ 
(A)

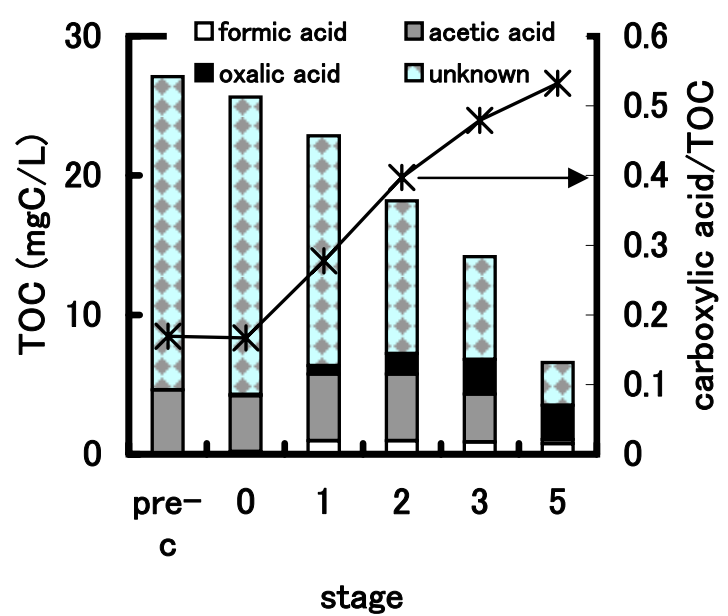

(B)

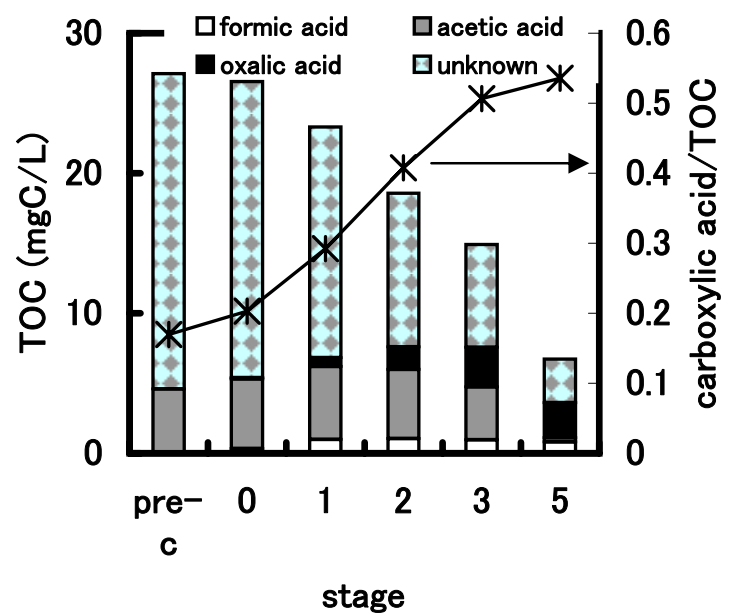

Fig. 12 Profiles of carboxylic acids ((A) Run6-2 \& (B) 6-3) ozonation (stage 0 ) and multi-stage ozone/hydrogen peroxide process (stage1-5) (pre-c: pre-coagulation) 
(A)

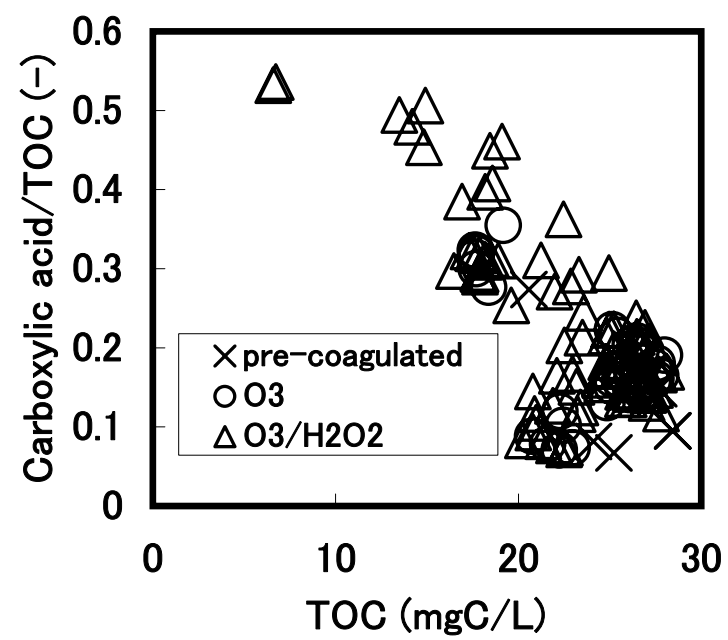

(B)

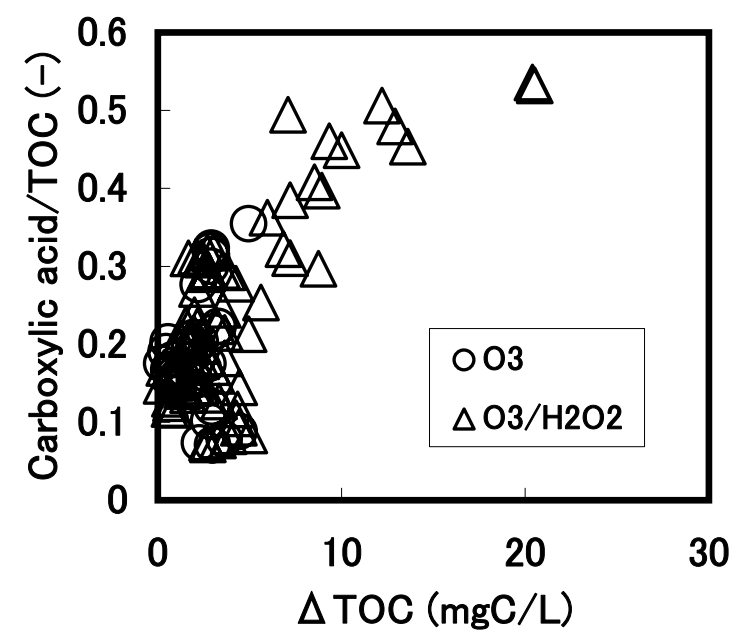

Fig. 13 (A) Ratio of carboxylic acids to TOC concentration as a function of TOC and (B) ratio of carboxylic acids to TOC as a function of removal amount of TOC during ozonation and $\mathrm{O}_{3} / \mathrm{H}_{2} \mathrm{O}_{2}$ 


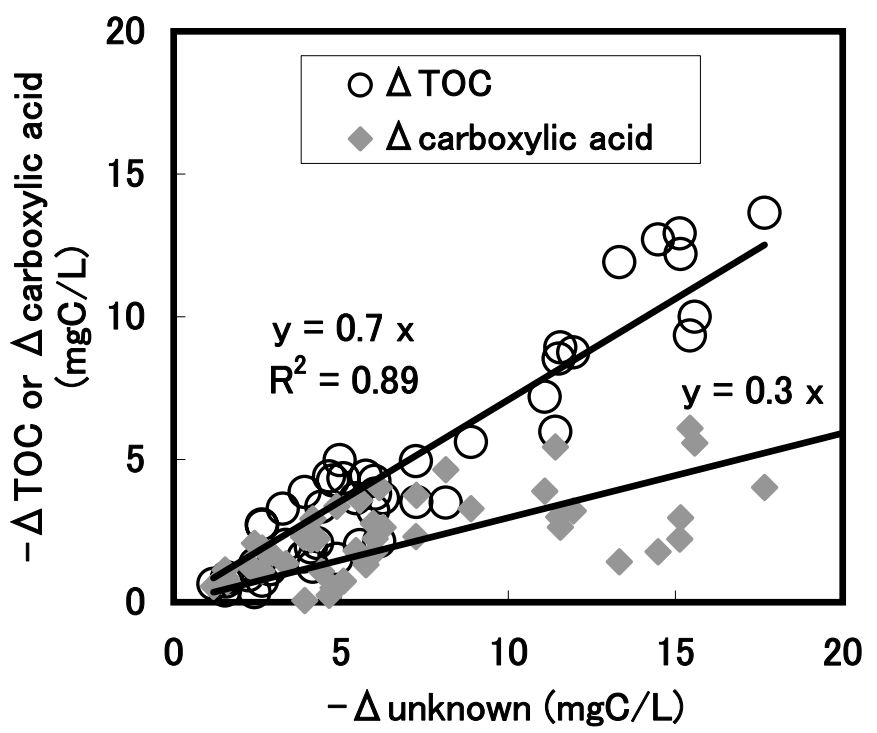

Fig. 14 Decrease of TOC and fromation of carboxylic acids as a function of decrease of unknown organic compounds 
(A)

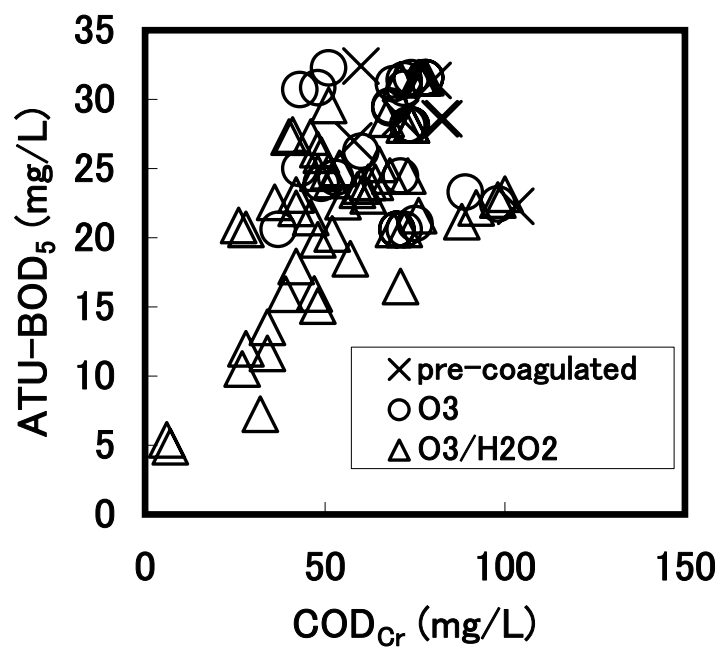

(B)

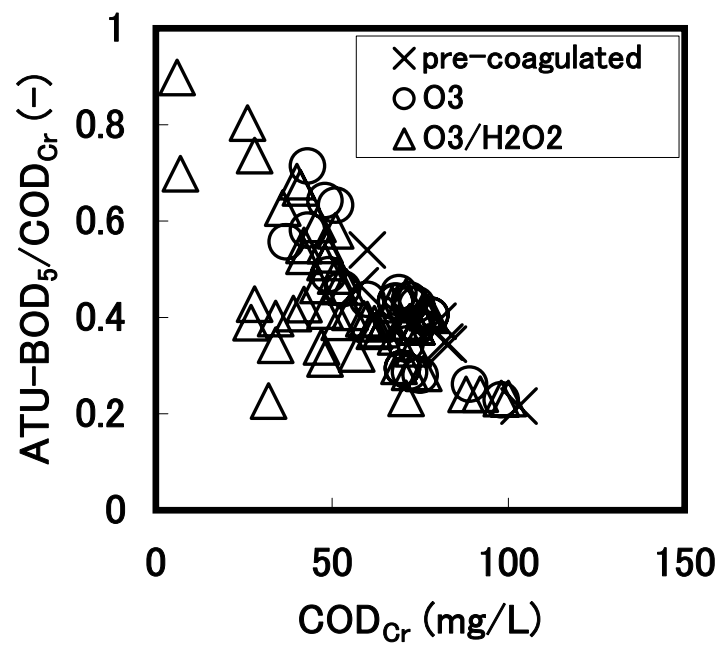

Fig. 15 Relationship between $C O D_{\mathrm{Cr}}$ and $A T U-\mathrm{BOD}_{5}$ during ozonation and $\mathrm{O}_{3} / \mathrm{H}_{2} \mathrm{O}_{2}$ ((A): ATU-BOD 5 as a function of $\mathrm{COD}_{\mathrm{Cr}}$, (B): ATU-BOD $5 / \mathrm{COD}_{\mathrm{Cr}}$ as a function of $\mathrm{COD}_{\mathrm{Cr}}$ ) 
Table 1 Water quality and pretreatment condition

\begin{tabular}{|c|c|c|c|c|}
\hline \multicolumn{3}{|c|}{ Item } & Raw sewage & $\begin{array}{l}\text { After } \\
\text { c. \& s }\end{array}$ \\
\hline \multirow{19}{*}{$\begin{array}{l}\text { Water } \\
\text { Quality }\end{array}$} & $\overline{\mathrm{SS}}$ & $\overline{\mathrm{mg} / \mathrm{L}}$ & $103 \sim 230$ & $\overline{1 \sim 9}$ \\
\hline & $\mathrm{T}-\mathrm{COD}_{\mathrm{Cr}}$ & $\mathrm{mg} / \mathrm{L}$ & $240 \sim 560$ & $58 \sim 103$ \\
\hline & $\mathrm{S}-\mathrm{COD}_{\mathrm{Cr}}$ & $\mathrm{mg} / \mathrm{L}$ & $114 \sim 178$ & $53 \sim 99$ \\
\hline & ATU-BOD 5 & $\mathrm{mg} / \mathrm{L}$ & $81 \sim 203$ & $22 \sim 32$ \\
\hline & TOC & $\mathrm{mgC} / \mathrm{L}$ & $85.8 \sim 168.3$ & $20.6 \sim 29.4$ \\
\hline & DOC & $\mathrm{mgC} / \mathrm{L}$ & $34.6 \sim 52.5$ & $18.5 \sim 27.1$ \\
\hline & IC & $\mathrm{mgC} / \mathrm{L}$ & $35.8 \sim 42.7$ & $18.1 \sim 25.8$ \\
\hline & $\mathrm{T}-\mathrm{N}$ & $\mathrm{mgN} / \mathrm{L}$ & $23 \sim 39$ & $21 \sim 29$ \\
\hline & $\mathrm{NH}_{4}^{+}$ & $\mathrm{mgN} / \mathrm{L}$ & $15 \sim 25$ & $15 \sim 21$ \\
\hline & $\mathrm{T}-\mathrm{P}$ & $\mathrm{mgP} / \mathrm{L}$ & $3.6 \sim 5.7$ & $\sim 0.5$ \\
\hline & $\mathrm{HCOOH}$ & $\mathrm{mgC} / \mathrm{L}$ & 0 & 0 \\
\hline & $\mathrm{CH}_{3} \mathrm{COOH}$ & $\mathrm{mgC} / \mathrm{L}$ & $1.6 \sim 5.6$ & $1.7 \sim 5.6$ \\
\hline & $(\mathrm{COOH})_{2}$ & $\mathrm{mgC} / \mathrm{L}$ & 0 & 0 \\
\hline & $\mathrm{NO}_{2}^{-}$ & $\mathrm{mgN} / \mathrm{L}$ & $\sim 0.1$ & $\sim 0.1$ \\
\hline & $\mathrm{NO}_{3}{ }^{-}$ & $\mathrm{mgN} / \mathrm{L}$ & $\sim 0.2$ & $\sim 0.2$ \\
\hline & $\mathrm{Br}^{-}$ & $\mu \mathrm{g} / \mathrm{L}$ & $550 \sim 740$ & $550 \sim 740$ \\
\hline & $\mathrm{BrO}_{3}^{-}$ & $\mu \mathrm{g} / \mathrm{L}$ & 0 & 0 \\
\hline & $\mathrm{pH}$ & - & $6.9 \sim 7.3$ & $5.8 \sim 6.5$ \\
\hline & $U_{254}$ & $\mathrm{~cm}^{-1}$ & $0.286 \sim 0.677$ & $0.138 \sim 0.257$ \\
\hline \multicolumn{5}{|c|}{ Coagulation and Sedimentation condition } \\
\hline \multicolumn{3}{|c|}{ Ferric chloride } & $\overline{\mathrm{mgFe} / \mathrm{L}}$ & $28 \sim 36$ \\
\hline \multicolumn{3}{|c|}{ Polymar (anion) } & $\mathrm{mg} / \mathrm{L}$ & $0.84 \sim 1.08$ \\
\hline \multirow{2}{*}{\multicolumn{3}{|c|}{$\begin{array}{l}\text { Rapid mixing (G value, time) } \\
\text { Slow mixing (G value, time) }\end{array}$}} & $1 / \mathrm{sec} ., \min$. & 100,3 \\
\hline & & & $1 /$ sec., $\min$. & 30,10 \\
\hline \multicolumn{3}{|c|}{ Sedimentation } & $\min$. & 30 \\
\hline
\end{tabular}

c. \& s.: coagulation \& sedimentation 
Table 2 Experimental condition

\begin{tabular}{|c|c|c|c|c|}
\hline Run & $\begin{array}{l}\text { Flow rate } \\
(\mathrm{mL} / \mathrm{min} .)\end{array}$ & $\begin{array}{c}\text { Gas conc. } \\
(\mathrm{mg} / \mathrm{L})\end{array}$ & $\begin{array}{c}\mathrm{H}_{2} \mathrm{O}_{2} \text { conc. } \\
(\mathrm{mg} / \mathrm{L})\end{array}$ & Other \\
\hline $1-1$ & $\begin{array}{l}50 \\
\end{array}$ & \multirow{3}{*}{50} & \multirow{3}{*}{0} & \\
\hline $1-2$ & 100 & & & \\
\hline $1-3$ & 200 & & & \\
\hline $2-1$ & \multirow{3}{*}{50} & 25 & \multirow{3}{*}{0} & \\
\hline $2-2$ & & 50 & & \\
\hline $2-3$ & & 100 & & \\
\hline $3-1$ & \multirow{3}{*}{50} & \multirow{3}{*}{50} & 0 & \\
\hline $3-2$ & & & 4 & \\
\hline $3-3$ & & & 15 & \\
\hline $4-1$ & \multirow{4}{*}{50} & \multirow{4}{*}{50} & 0 & \\
\hline $4-2$ & & & 4 & \\
\hline $4-3$ & & & 15 & \\
\hline $4-4$ & & & 50 & \\
\hline $5-1-1$ & \multirow{3}{*}{50} & \multirow{3}{*}{50} & 0 & \\
\hline $5-1-2$ & & & 3 & \\
\hline $5-1-3$ & & & 5 & \\
\hline $5-2-1$ & \multirow{3}{*}{50} & \multirow{3}{*}{100} & 0 & \\
\hline $5-2-2$ & & & 3 & \\
\hline $5-2-3$ & & & 10 & \\
\hline $5-3-1$ & \multirow{3}{*}{100} & \multirow{3}{*}{50} & 0 & \\
\hline $5-3-2$ & & & 3 & \\
\hline $5-3-3$ & & & 10 & \\
\hline \multirow{2}{*}{$6-1$} & \multirow{2}{*}{50} & \multirow{2}{*}{50} & 0 & $7 \mathrm{~min} . \times 1$ stage \\
\hline & & & 2 & $15 \mathrm{~min} . \times 2$ stages \\
\hline \multirow{2}{*}{$6-2$} & \multirow{2}{*}{50} & \multirow{2}{*}{100} & 0 & 4 min. $x$ 1stage \\
\hline & & & 5 & $15 \mathrm{~min} . \times 5$ stages \\
\hline \multirow{2}{*}{$6-3$} & \multirow{2}{*}{100} & \multirow{2}{*}{50} & 0 & 4 min. $x$ 1stage \\
\hline & & & 5 & $15 \mathrm{~min} . \times$ stages \\
\hline
\end{tabular}


Table 3 Analytical method and instrument

\begin{tabular}{|c|c|c|c|}
\hline \multicolumn{3}{|c|}{ Item } & Analytical method and instrument \\
\hline \multirow{19}{*}{$\begin{array}{l}\text { Water } \\
\text { Quality }\end{array}$} & SS & $\mathrm{mg} / \mathrm{L}$ & Glass-fiber filter method \\
\hline & $\mathrm{T}-\mathrm{COD}_{\mathrm{Cr}}$ & $\mathrm{mg} / \mathrm{L}$ & Closed reflux, Colorimetic method \\
\hline & $\mathrm{S}-\mathrm{COD}_{\mathrm{Cr}}$ & $\mathrm{mg} / \mathrm{L}$ & Closed reflux, Colorimetic method \\
\hline & $\mathrm{ATU}^{-\mathrm{BOD}_{5}}$ & $\mathrm{mg} / \mathrm{L}$ & 5 -day BOD test \\
\hline & TOC & $\mathrm{mgC} / \mathrm{L}$ & High temperature combustion method (SHIMADZU, TOC- $\mathrm{V}_{\mathrm{CSH}}$ ) \\
\hline & $\mathrm{DOC}$ & $\mathrm{mgC} / \mathrm{L}$ & High temperature combustion method (SHIMADZU, TOC- $\mathrm{V}_{\mathrm{CSH}}$ ) \\
\hline & IC & $\mathrm{mgC} / \mathrm{L}$ & High temperature combustion method (SHIMADZU, TOC- $\mathrm{V}_{\mathrm{CSH}}$ ) \\
\hline & $\mathrm{T}-\mathrm{N}$ & $\mathrm{mgN} / \mathrm{L}$ & $\begin{array}{l}\text { Manual digestion (alkali persulfate digestion) and } \\
\text { flow injection analysis (cadmium reduction, N-(1-naphthyl ethylendiamine method) } \\
\text { (BRAN+LUEBBE, AACSII) }\end{array}$ \\
\hline & $\mathrm{NH}_{4}^{+}$ & $\mathrm{mgN} / \mathrm{L}$ & Phanate method \\
\hline & $\mathrm{T}-\mathrm{P}$ & $\mathrm{mgP} / \mathrm{L}$ & $\begin{array}{l}\text { Manual digestion (acid persulfate digestion) and flow injection analysis (molybdate color method) } \\
\text { (BRAN+LUEBBE, AACSII) }\end{array}$ \\
\hline & $\mathrm{HCOOH}$ & $\mathrm{mgC} / \mathrm{L}$ & Ion chromatographic method (DIONEX, DX-500) \\
\hline & $\mathrm{CH}_{3} \mathrm{COOH}$ & $\mathrm{mgC} / \mathrm{L}$ & Ion chromatographic method (DIONEX, DX-500) \\
\hline & $(\mathrm{COOH})_{2}$ & $\mathrm{mgC} / \mathrm{L}$ & Ion chromatographic method (DIONEX, DX-500) \\
\hline & $\mathrm{NO}_{2}^{-}$ & $\mathrm{mgN} / \mathrm{L}$ & Ion chromatographic method (DIONEX, DX-500) \\
\hline & $\mathrm{NO}_{3}^{-}$ & $\mathrm{mgN} / \mathrm{L}$ & Ion chromatographic method (DIONEX, DX-500) \\
\hline & $\mathrm{Br}^{-}$ & $\mu \mathrm{g} / \mathrm{L}$ & Ion chromatographic method (DIONEX, DX-500) \\
\hline & $\mathrm{BrO}_{3}^{-}$ & $\mu \mathrm{g} / \mathrm{L}$ & Ion chromatographic method (o-dianisidin method) (DIONEX, DX-500) \\
\hline & $\mathrm{pH}$ & - & Electrometric method (HORIBA, pH meter D-25) \\
\hline & $\mathrm{UV}_{254}$ & $1 / \mathrm{cm}$ & Ultraviolet absorption method (SHIMADZU, UV-1600) \\
\hline \multirow{4}{*}{$\begin{array}{l}\text { Ozone \& } \\
\text { Hydrogen } \\
\text { peroxide }\end{array}$} & Dissolved & $\mathrm{mg} . / \mathrm{L}$ & Indigo method \\
\hline & Input gas & mg./L & Ozone gas monitor (spectrophotometric method) (EBARA JITUGYO, EG-600) \\
\hline & Exhaust gas & $\mathrm{mg} . / \mathrm{L}$ & KI titration method \\
\hline & Hydrogen peroxide & $\mathrm{mg} / \mathrm{L}$ & DMP method \\
\hline
\end{tabular}


Table 4 Analytical condition of ion chromatographic method

\begin{tabular}{|c|c|}
\hline Ion chromatograph & DX-500 (Dionex) \\
\hline Column & $\begin{array}{l}\text { IonPac AS9-HC (analytical column) } \\
\text { IonPac AG9-HC (guard column) }\end{array}$ \\
\hline Eluent & $\begin{array}{l}9 \mathrm{mM} \mathrm{Na}_{2} \mathrm{CO}_{3} \\
\text { Flow rate } 1.0 \mathrm{~mL} / \mathrm{min}\end{array}$ \\
\hline Auto suppressor & $\begin{array}{l}\text { ASRS-Ultra (external water mode) } \\
\text { Electric current } 100 \mathrm{~mA}\end{array}$ \\
\hline Injection volume & $100 \mu \mathrm{L}$ \\
\hline Detector & $\begin{array}{l}\text { CD20 (conductivity detector) } \\
\text { UV/VIS (210nm) }\end{array}$ \\
\hline Post column & $\begin{array}{l}\text {-dianisidin method } \\
\text { Flow rate } 0.3 \mathrm{~mL} / \mathrm{min} . \\
\text { Temperature } 60{ }^{\circ} \mathrm{C} \\
\text { UV/VIS }(450 \mathrm{~nm})\end{array}$ \\
\hline
\end{tabular}

